\title{
MEASUREMENT OF TRANS FATTY ACIDS IN READY TO EAT CHICKEN MEAT
}

\author{
ZEINAB AHMED ${ }^{1}$ and SUZAN F. EL-SISY ${ }^{2}$ \\ ${ }^{1}$ Agriculture Research Center, Animal Health Research Institute, Reference Laboratory for Veterinary \\ Quality Control on Poultry production (RLQP), Luxor, Egypt, Dokki, Giza, \\ ${ }^{2}$ Agriculture Research Center, Animal Health Research Institute, Benha, Egypt, Dokki, Giza
}

Received: 31 December 2020; Accepted: 30 March 2021

\begin{abstract}
High intake of TFA leads to more health problems as heart disease, breast cancer and diabetes. So we worked in this study for measurement of trans fatty acids (TFA) of ninety ready to eat chicken meat samples from restaurants of Luxor city, and effect of different material of fried on TFA to help people and tourists for determined awareness of TFA in these restaurants and material of fried. In this study found mean of TFA and elaidic acid in chicken burger samples $(1.813 \mathrm{mg} \backslash 100 \mathrm{gm}, \pm 0.151 \mathrm{mg} \backslash 100 \mathrm{gm}$, and $1.450 \mathrm{mg} \backslash 100 \mathrm{gm}$, respectively). In fried chicken samples $(0.159 \mathrm{mg} \backslash 100 \mathrm{gm}, \pm 0.024 \mathrm{mg} \backslash 100 \mathrm{gm}$, and 0.127 $\mathrm{mg} \backslash 100 \mathrm{gm}$, respectively), and in chicken shawirma samples $(4.016 \mathrm{mg} \backslash 100 \mathrm{gm}, \pm 0.583$ $\mathrm{mg} \backslash 100 \mathrm{gm}$, and $3.212 \mathrm{mg} \backslash 100 \mathrm{gm}$, respectively). In this study also an experiment to what happens of TFA in ready to eat chicken meat when used of vegetable oil, butter, or margarine was carried out. It was found TFA of chicken burger, fried chicken and chicken shawirma with use of oil (0.343 mg\100 gm, $0.065 \mathrm{mg} \backslash 100 \mathrm{gm}$, and $1.622 \mathrm{mg} \backslash 100 \mathrm{gm}$, respectively). TFA of chicken burger, fried chicken and chicken shawirma use of butter (1.836 mg $100 \mathrm{gm}$, 12.855, and $0.446 \mathrm{mg} \backslash 100 \mathrm{gm}$, respectively). TFA of chicken burger, fried chicken, Chicken shawirma which use of margarine $(3.278 \mathrm{mg} \backslash 100 \mathrm{gm}, 4.139 \mathrm{mg} \backslash 100 \mathrm{gm}$, and $3.22 \mathrm{mg} \backslash 100$ gm, respectively). In conclusion: throughout the samples analysis in our study, chicken shawirma samples from restaurants showed the highest content of trans fatty acids and elaidic acid. The TFA formation was found to be varied with the food ingredient and with the material used for frying.
\end{abstract}

Keywords: Trans fatty acid; ready to eat; chicken meat

\section{INTRODUCTION}

Trans fatty acids are dangerous fats produced by heating liquid vegetable oils in

Corresponding author: Zeinab Ahmed

E-mail address: zeinabrenad@gmail.com

Present address: Agriculture Research Center,

Animal Health Research Institute, Reference Laboratory for Veterinary Quality Control on Poultry production (RLQP), Luxor, Egypt, Dokki, Giza, the presence of hydrogen. Fast foods contain up to $50 \%$ trans fatty acids. Trans fatty acids have been increase LDL cholesterol and lower HDL cholesterol, which may increase the risk for heart disease (Mozaffarian et al., 2006). Trans fatty acids in food are derived from three main sources, including (1) hydrogenation of oils and fats, which used in industrial process (2) biotransformation by bacteria in 
the stomach of a ruminant animal, resulting in the natural presence of TFA in milk, milk products, and meat from these animals and (3) heat treatments such as commercial deep frying and cooking at high temperatures (Hénon et al., 1999). Trans fatty acids formed industrially during the partial hydrogenation of commercial liquid vegetable oils to semi-solid fats are found in margarine and frying fats. Intake of trans fatty acids is associated with metabolic and inflammatory risk factors and diseases. It was recommends that trans fatty acids intake be limited to less than $1 \%$ of total energy intake (WHO, 2008). According to FDA about $5.6 \mathrm{~g}$ of trans fatty acids was consumed per day. Consumption of trans fatty acids has shown to increase the risk of coronary heart disease (FDA, 2003). Amount of trans fatty acids in a serving of food is $0.5 \mathrm{~g}$ or more according to FDA (Dhaka et al., 2011). Commercial frying oil contain significant amount of trans fatty acids there for fried fast food items as french fries and fried chicken contain significant amount of trans fatty acids (Enig et al., 1990). The major trans fatty acids is C18:1tran-9 elaidic acid (Wanders et al., 2010). High intake trans fatty acids increases the risk of coronary heart disease, diabetes mellitus, myocardial infraction and risk of pregnancy induced hypertension (Grundy, 2002; Clifton et al., 2004; YLiJama et al., 2002). Association between the adipose concentration of trans fatty acids and breast cancer there is the risk of breast cancer increase with increase in trans fatty acids level in blood serum of women (Kim et al., 2006). Trans fatty acids has also been implicated in systemic inflammation, endothelial dysfunction, adiposity, and insulin resistance (Micha and Mozzaffarian, 2008).

Trans fatty acids cause more health problems so aimed of this study to determination of trans fatty acids in ready to eat chicken meat in Luxor city restaurants. Besides, the present study was designed to keep track of a real-life path to what happens in trans fatty acids in ready to eat chicken meat when frying on oil, butter, or margarine.

\section{MATERIALS AND METHOD}

\section{Collection of restaurant samples:}

A total of 90 random samples of ready to eat chicken meat including chicken burger, fried chicken and chicken shawirma (30 of each product) were collected from different restaurants in Luxor city. Each sample was kept in a separate sterile plastic bag and put in an ice box. The samples were well labeled and transferred to chemistry unite of animal health research institute, Egypt, Dokki, Giza under complete aseptic condition without undue delay for measurement of trans fatty acids

\section{Experimental for measurement trans fatty acids in ready to eat chicken meat prepared at home and used of oil, butter, or margarine:}

Nine Nine samples from chicken burger, fried chicken and chicken shawirma (3 of each product) were prepared for cooking. Apiece of chicken burger (1) was fried in vegetable oil, a piece of chicken burger (2) was fried in butter and a piece of chicken burger (3) was fried in margarine. A piece of fried chicken (4) in vegetable oil, a piece of fried chicken (5) in butter and a piece of fried chicken (6) in margarine, and a piece of chicken shawirma (7) in vegetable oil, a piece of chicken shawirma (8) in butter, and a piece of chicken shawirma (9) in margarine, until complete cooking. Each sample was kept in a separate sterile plastic bag, put in an ice box, well labeled, prepared to be transferred to chemistry unite of animal health research institute, Egypt, Dokki, Giza under complete aseptic conditions without undue delay for determination of trans fatty acids

\section{Analysis of Trans Fatty Acids According to (Jayasena et al., 2013):}




\subsection{Sample Preparation and Fat} Extraction (Jayasena et al., 2013):

Samples were grinded then add Glycrel Tritridecanoate at concentration of $200 \mu \mathrm{g} / \mathrm{ml}$ by adding $20 \mathrm{ml}$ of the stock solution (1mg/ml Dichloromethane). Then solvent of the glyceryl tritridecanoate (dichloromethane) was evaporated by applying nitrogen flow without any heat. Afterward, accurately $40 \mathrm{ml}$ of chloroform, $20 \mathrm{ml}$ of methane and $12 \mathrm{ml}$ of deionized water into the spiked sample were added after that filtration

\subsection{Preparation of methyl esters and derivatization of the extraction (Jayasena et al., 2013):}

Before the derivatization, $1 \mathrm{ml}$ of the chloroform extraction transferred to a screw cap test tube and evaporated by nitrogen flow without any heat using a Reacti-Vap Evaporator to remove the chloroform from the extract. The evaporated $1 \mathrm{ml}$ was treated with $7 \mathrm{ml}$ of derivatizing solution (Boron trifloridemethanol GC derivatization grade $\left(\begin{array}{ll}\sim 10 \% & \sim 1.3 \mathrm{M})\end{array}\right)$ after tightly closed till disappearing of fat globules and saponification was carried out at approximately $70^{\circ} \mathrm{C}$ in Driblock DB-3H (Tecam) before GC/FID analysis. After the test tube was cooled, $1 \mathrm{ml}$ of water and $1 \mathrm{ml}$ of hexane was added to the solution then was shaken very well to force the esters into the hexane layer. The hexane layer was transferred into another test tube which contained a pinch of sodium sulphate as a water scavenger to remove any residual water. The dried hexane transferred into labeled GC vial for analysis.

\subsection{Gas Chromatography analysis (Jayasena et al., 2013):}

The quantification of the whole profile of the fatty acids include trans fatty acids levels in samples was performed using a GC/FID (Gas chromatography/Flame ignition detector) Agilent (7890B) equipped with a capillary column SP-2560 (Fused silica) Supelco (length $100 \mathrm{~m} x$ I.D. $0.25 \mathrm{~mm}$ $x$ D.F. $0.25 \mathrm{~mm}$ ) (Beliefonte, PA). Gas chromatography found in chemistry unites of animal health research institute, Egypt, Dokki, Giza.

\subsection{Statistical analysis}

Results from three repetitions of frying were collected and were analyzed by SAS system (Statistical Analysis System). Data were analyzed by single factor analysis of variance (ANOVA).

\section{RESULT}

Table 1: Incidence of total trans fatty acids and elaidic acid content in restaurants samples.

\begin{tabular}{cccc}
\hline & chicken burger & fried chicken & chicken shawirma \\
\hline Mean & $1.813 \mathrm{mg} \backslash 100 \mathrm{gm}$ & $0.159 \mathrm{mg} \backslash 100 \mathrm{gm}$ & $4.016 \mathrm{mg} \backslash 100 \mathrm{gm}$ \\
\hline SE & $0.151 \mathrm{mg} \backslash 100 \mathrm{gm}$ & $0.024 \mathrm{mg} \backslash 100 \mathrm{gm}$ & $0.583 \mathrm{mg} \backslash 100 \mathrm{gm}$ \\
\hline Elaidic acid & $1.450 \mathrm{mg} \backslash 100 \mathrm{gm}$ & $0.127 \mathrm{mg} \backslash 100 \mathrm{gm}$ & $3.212 \mathrm{mg} \backslash 100 \mathrm{gm}$ \\
\hline
\end{tabular}

High trans fatty acids in chicken shawirma samples

High eliadic acid in chicken shawirma samples

Table 2: Effect of frying process on content of trans fatty acids by use of oil, butter, or margarine in cooking of home prepared chicken burger, fried chicken, and chicken shawirma.

\begin{tabular}{cccc}
\hline Samples & TFA in vegetable oil & TFA in butter & TFA in margarine \\
\hline chicken burger $(1,2,3)$ & $0.343 \mathrm{mg} \backslash 100 \mathrm{gm}$ & $1.836 \mathrm{mg} \backslash 100 \mathrm{gm}$ & $3.278 \mathrm{mg} \backslash 100 \mathrm{gm}$ \\
\hline fried chicken $(4,5,6)$ & $0.065 \mathrm{mg} \backslash 100 \mathrm{gm}$ & $12.855 \mathrm{mg} \backslash 100 \mathrm{gm}$ & $4.139 \mathrm{mg} \backslash 100 \mathrm{gm}$ \\
\hline chicken shawirma $(7,8,9)$ & $1.622 \mathrm{mg} \backslash 100 \mathrm{gm}$ & $0.446 \mathrm{mg} \backslash 100 \mathrm{gm}$ & $3.22 \mathrm{mg} \backslash 100 \mathrm{gm}$ \\
\hline
\end{tabular}

High trans fatty acids in all of samples which use margarine in cooking

High trans fatty acids in fried chicken samples (5) which use butter in cooking 


\section{DISCUSSION}

The limit intake from trans fatty acids not let than $1 \%$ (approximately $2 \mathrm{~g} /$ day) of total energy according to WHO (Yamada et al., 2010). High consumption of trans fatty acids may increase the risk of heart attack (EFSA, 2004). Trans fatty acids intake was positively associated with the incidence of diabetes with a risk of up to $39 \mathrm{mg} \backslash 100 \mathrm{gm}$ (Meyer et al., 2001). So we worked this study for determination of TFA in restaurants of Luxor city and effect of using different material of fried on TFA to help people and tourist for now awareness of TFA in theses restaurant and material of fried.

In our study in table 1 mean of TFA 1.813 mg\100 gm in chicken burger this limit high little than WHO limit (not let than $1 \%$ ) and similar to (Akmar et al., 2013), who detected TFA in chicken burger 1.97 mg\100 gm, and lower than (Church, 2008), who detected TFA in chicken burger $\leq 2$ $\mathrm{mg} \backslash 100 \mathrm{gm}$, Elaidic acid in chicken burger was $1.450 \mathrm{mg} \backslash 100 \mathrm{gm}$, that indicated TFA from ingredients such as hydrogenated oils and some products of animal origin had a higher ratio of elaidic acid as expected (FSAI, 2008). In our study fried chicken have TFA $0.159 \mathrm{mg} \backslash 100 \mathrm{gm}$, these result similar to (Lee et al., 2010) who detected TFA $0.14 \mathrm{mg} \backslash 100 \mathrm{gm}$, in fried chicken but lower than (Fu et al., 2008) who detected TFA $8.81 \mathrm{mg} \backslash 100 \mathrm{gm}$, in fried chicken. Elaidic acid in fried chicken $0.127 \mathrm{mg} \backslash 100$ $\mathrm{gm}$, that consider in range of $\mathrm{WHO}$ and lower than (Ahmed et al., 2020) who detected elaidic in fried chicken 0.1987 mgl100 gm, and higher than (Akmar et al., 2013) who detected elaidic acid in fried chicken $<0.001 \mathrm{mg} \backslash 100 \mathrm{gm}$,

In cooking used of corn oil for frying chicken meat at a temperature of $170^{\circ} \mathrm{C}$ for 4 minutes did not induce the formation of trans fatty acids in the meat (Yang et al., 2014). In current study chicken shawirma have TFA $4.016 \mathrm{mg} \backslash 100 \mathrm{gm}$, this result more than WHO limit (not let than $1 \%$ ) that indicated the part of chicken contained skin which high in TFA and ingredients in shawirma as vegetables high in TFA. Formation of varied amounts of TFAs increase according to frying temperature, ingredients and the oil used (Liu et al., 2007). Some liquid vegetable oils such as canola and soybean, contain small amounts of TFA which can be formed during the commercial refinement of these oils (Ratnayake and Zehaluk, 2005). The continuous using of frying oil might produce certain harmful toxic compounds to human health such as oxidized fatty acids, trans fatty acids (Ganbi, 2011).

In table 2 in these results use of margarine in cooking lead to increase of TFA more than the limit of WHO in chicken burger, fried chicken and chicken shawirma (3.278 $\mathrm{mg} \backslash 100 \mathrm{gm}, 4.139 \mathrm{mg} \backslash 100 \mathrm{gm}$, and 3.22 mg\100 gm,). These results lower than (Yamada et al., 2010) who detected TFA content for margarine $5.8 \mathrm{mg} \backslash 100 \mathrm{gm}$ and these results also lower than (Ratnayake and Zehaluk, 2005) who detected TFA content for margarine that used in ready to eat chicken meat $(14.7 \mathrm{mg} \backslash 100 \mathrm{gm},-21.0$ mg\100 gm), and similar to (Wood et al., 1993) who detected TFA content for margarine that used in ready to eat chicken meat (3.4 mg\100 gm,). High intake of TFA lead to more health problems, in this result due to fried chicken carry high TFA in subcutaneous fat and deep frying lead to increase of TFA so its result is more them. Chicken fats are mostly unsaturated and found in skin so during frying, these give TFA (Goburdhun et al., 2000). In present result use of butter in cooking not increases TFA more than the limit of WHO (not let than $1 \%$ ), in chicken burger and chicken shawirma (1.836 mg\100 gm, and 0.446 mg\100 gm, respectively). These results were lower than (Wood et al., 1993) who detected TFA (5.3 mg $\backslash 100 \mathrm{gm}$ ), in butter. However in fried chicken TFA (12.855 mg\100 gm,) was more than normal limit of 
WHO and dangerous. The high result because chicken fats in skin or thigh are mostly unsaturated and during frying, these will melt and seep out into the frying medium, where rapidly oxidized to give more TFA (Goburdhun et al., 2000). Deep frying of chicken despite responsible for good flavor and color, however generates many of hazardous compounds, such as TFA which are formed in food during frying in high temperatures (Choe and Min, 2007). Frying chicken thigh did not result in the formation of trans fatty acids in the meat but TFA appeared in the skin of the meat fried because of the absorption of the oil. The maximum trans fatty acid content was obtained after 15 minutes of frying (Liuet et al., 2008). Trans fatty acids can be formed when vegetable oils are converted to solid fats such as margarine and other fats by an industrial process called hydrogenation. Foods in which the hydrogenated oils are used as ingredients may contain industrial trans fatty acids which found in small amounts during the refining of liquid vegetable oils (Mehta and Swinburn, 2001). Heat treatments such as commercial deep frying and cooking at high temperatures lead to increase TFA in restaurant food (Hénon et al., 1999). In our study use of oil in cooking lead to not increase of TFA according to the limit of WHO (not let than $1 \%$ ) in chicken burger, fried chicken and chicken shawirma $(0.343$ $\mathrm{mg} \backslash 100 \mathrm{gm}, 0.065 \mathrm{mg} \backslash 100 \mathrm{gm}$, and 1.622 mg\100 gm, respectively). These results similar to (Asgary et al., 2009) who detected TFA $0.9 \mathrm{mg} \backslash 100 \mathrm{gm}$, on foods French fries and fried chicken

\section{CONCLUSION}

Chicken shawirma samples from restaurants showed the highest content of trans fatty acids and eliadic acid which may attributed to ingredients in shawirma as vegetables high in TFA. Formation of varied amounts of TFA increase according to frying temperature, ingredients and the oil used. Fried chicken with use of butter and margarine show highest TFA, and highest value with use of butter, which may related to the increase of fat in the skin and thigh of piece of chicken used. The high variability of TFA content in samples could related to several factors as the lipid composition of the food, differences in cooking methods, fast food preparation and ingredient content, deep frying, food surface area for fat absorption, high temperature use in cooking and major of them type of vegetable oil used for food preparation. It is possible to minimize trans fatty acids during the hydrogenation by increasing the pressure, catalyst concentration and agitation. All these technologies were oil formulation, so must be lead to decrease TFA in food to avoid health problems

\section{REFERENCES}

Ahmed, N.I.H.; Ahmed, A.M.; Yassin, M.A.M. and Gruen, I. (2020): Effect of deep frying on fatty acids profile of fried chicken and tilapia, SCVMJ, XXV, 1: 173.

Akmar, ZD.; Norhaizan, ME.; Azimah, R.; Azrina, A. and Chan, YM. (2013): The Trans Fatty Acids Content of Selected Foods in Malaysia Mal J Nutr, 19 (1): 87 - 98.

Asgary, S.; Nazari, B.; Sarrafzadegan, N.; Saberi, S.; Azadbakht, and Esmaillzadeh, A. (2009): Fatty acid composition of commercially available Iranian edible oils. J Res Med Sci, 14 (4): 211-215.

Choe, E. and Min, D. (2007): Chemistry of deep-fat frying oils. Journal of food science, 72: R77-R86.

Church, S. (2008): Trends in Portion Sizes in the UK - A Preliminary Review of Published Information. Report to the Food Standards Agency UK.

Clifton, P.M.; Keogh, J.B. and Noakes, M. (2004): Trans Fatty Acid in adipose tissue and the food supply are 
associated with myocardial infraction The Journal of Nutrition, 134 (4): 874-879.

Dhaka, V.; Gulia, N.; Ahlawat, KS. and Khatkar, BS. (2011): Trans fatsSources, health risks and alternative approach - A review. J. Food Sci Technol, 48 (5): 534-541.

EFSA (2004): European Food Safety Authority, Opinion of the scientific panel on dietetic products, nutrition and allergies on a request from the commission related to the presence of Trans fatty acids in foods and the effect on human health of the consumption of Trans fatty acids. The EFSA Journal, 81: 1-49.

Enig, M.G.; Atal, S.; Keeny M. and Sampugna, J. (1990): Isomeric Trans Fatty Acid in the US diet " The Journal of the American of Nutrition, 9 (5): 417-486.

FDA (2003): Department of Health and Human Services Food labeling: Trans Fatty Acid in nutrition labeling Federal Registration, 68: 4143441506.

FSAI (2008): Trans Fatty Acid Survey of Fast Foods in Ireland. From http://www.fsai.ie/resources_and_pub lications/surverys.html.

Fu, H.; Yang, L.; Yuan, H.; Rao, P. and Lo, YM. (2008): Assessment of Trans fatty acids content in popular western-style products in China. J Food Sci, 73: S383-S391.

Ganbi, H.H.A. (2011): Alteration in fatty acid profiles and formation of some harmful compounds in hammour fish fillets and frying oil medium throughout intermittent deep-fat frying process. World Appl Sci J, 12: 536-44.

Goburdhun, D.; Seebun, P. and Ruggoo, A. (2000): Effect of deep-fat frying of potato chips and chicken on the quality of soybean oil. Journal of Consumer Studies and Home Economics, 24: 223-233.
Grundy, S.M. (2002): "low density lipoprotein, non- high density lipoprotein and lipoprotein B as targets of lipid- lowering therapy: Circulation, 106 (20): 2526-2529.

Hénon, G.; Kemény, Zs.; Recseg, K.; Zwobada, F. and Kovarik, K. (1999): Deodorization of vegetable oils. Part I: Modeling the geometrical isomerization of polyunsaturated fatty acids. J AM Oil chem soc, 76: 73-81.

Jayasena, D.D.; Jung, S.; Kim, H.J.; Bae, Y.S.; Yong, H.I.; Lee, J.H.; Kim, J.G. and Jo, C. (2013): Comparison of quality traits of meat from Korean native chickens and broilers used in two different traditional Korean cuisines. Asian-Australasian Journal of Animal Sciences, 26: 1038.

Kim, EH.; Willett, WC. and Colditz, GA. (2006): Dietary fat and risk of postmenopausal breast cancer in a 20year follow-up. Am J Epidemiol, 164: 990-997.

Lee, JH.; Adhikari, P.; Kim, SA.; Yoon, T.; Kim, IH. and Lee, KT. (2010): Trans fatty acids fatty acid profiles in the selected food products. J Food Sci 75 (7): C647

Liu, W.; Inbaraj, B.S. and Chen, B. (2007): Analysis and formation of trans fatty acids in hydrogenated soybean oil during heating. Food Chemistry, 104: 1740-1749.

Liut, WH.; Lu, YF.; Stephen, IB. and Chen, BH. (2008): Formation of Trans fatty acids in chicken legs during frying. International Journal of Food Science and Nutrition, 59 (5): 368-382.

Mehta, U. and Swinburn, B. (2001): A review of factors affecting fat absorption in hot chips. Critical Reviews in Food Science and Nutrition, 41(2): 133-154.

Meyer, KA.; Kushi, LH.; Jacobs, DRJr. and Folsom, AR. (2001): Dietary fat and incidence of type 2 diabetes in older Iowa women. Diabetes Care 24: 1528-35. 
Micha, R. and Mozzaffarian, D. (2008): Protag. Leukotr. Essent. Fatty Acids 79: 147-152.

Mozaffarian, D.; Katan, M.B.; Ascherio, A.; Stampfer, M.J. and Willett, W.C. (2006): "trans fatty acid and cardiovascular disease." New England Journal of Medicine, 354 (15): 16011613.

Ratnayake, W.M.N. and Zehaluk, C. (2005): in Healthful Lipids, C.C. Akoh and O.-M. Lai (Eds), AOCS Press Champaign, IL, pp 1-32.

Wanders, A.J.; Bouwer, E.; Siebelink, M.B. and Katan, A.C. (2010): Effect of high intake of conjugated linoleic acid on lipoprotein levels in healthy human subjects. PloS one, 5 (2): e 9000 .

WHO (2008): Diet, Nutrition and the Prevention of Chronic Diseases Joint WHO/FAO Expert Consultation. WHO Technical Report Series no. 916. Geneva.

Wood, R.; Kubena, K.; O’Brien, B.; Tseng, S. and Martin, G. (1993): Effect of butter, mono- and polyunsaturated fatty acid-enriched butter, Trans fatty acids margarine, and zero trans fatty acids margarine on serum lipids and lipoproteins in healthy men. Journal of Lipid Research, 34: 1-11.

Yamada, H.; Sasaki, S.; Murakami, K.; Takahashi, Y.; Okubo, H.; Hirota, N.; Notsu, A.; Todoriki, H.; Miura, A.; Fukui, M. and Date, Ch. (2010): Estimation of trans fatty acids intake in Japanese adults using16-day diet records based on a food composition data base developed for the Japanese population. Journal of Epidemiol, 20 (2): 119-127.

Yang, M.; Yang, Y.; Nie, S.; Xie, M.; Chen, $F$. and Luo, PG. (2014): Formation of trans fatty acids during the frying of chicken fillet in corn oil. International Journal of Food Science and Nutrition, 65 (3): 306-310.

YLi-Jama, P.; Meyer, H.E.; Ringstad, J. and Pedersen, J.I. (2002): Serum free fatty acid pattern and risk of myocardial infraction: a case-control study. Journal of Internal Medicine, 251: 19- 28.

\section{قياس الدهون المتحولة فى لحوم الدواجن الجاهزة للاستهلاك}

\section{زينب /حمد ، سوزان فوزى السيسى}

E-mail: zeinabrenad@gmail.com Assiut University web-site: www.aun.edu.eg

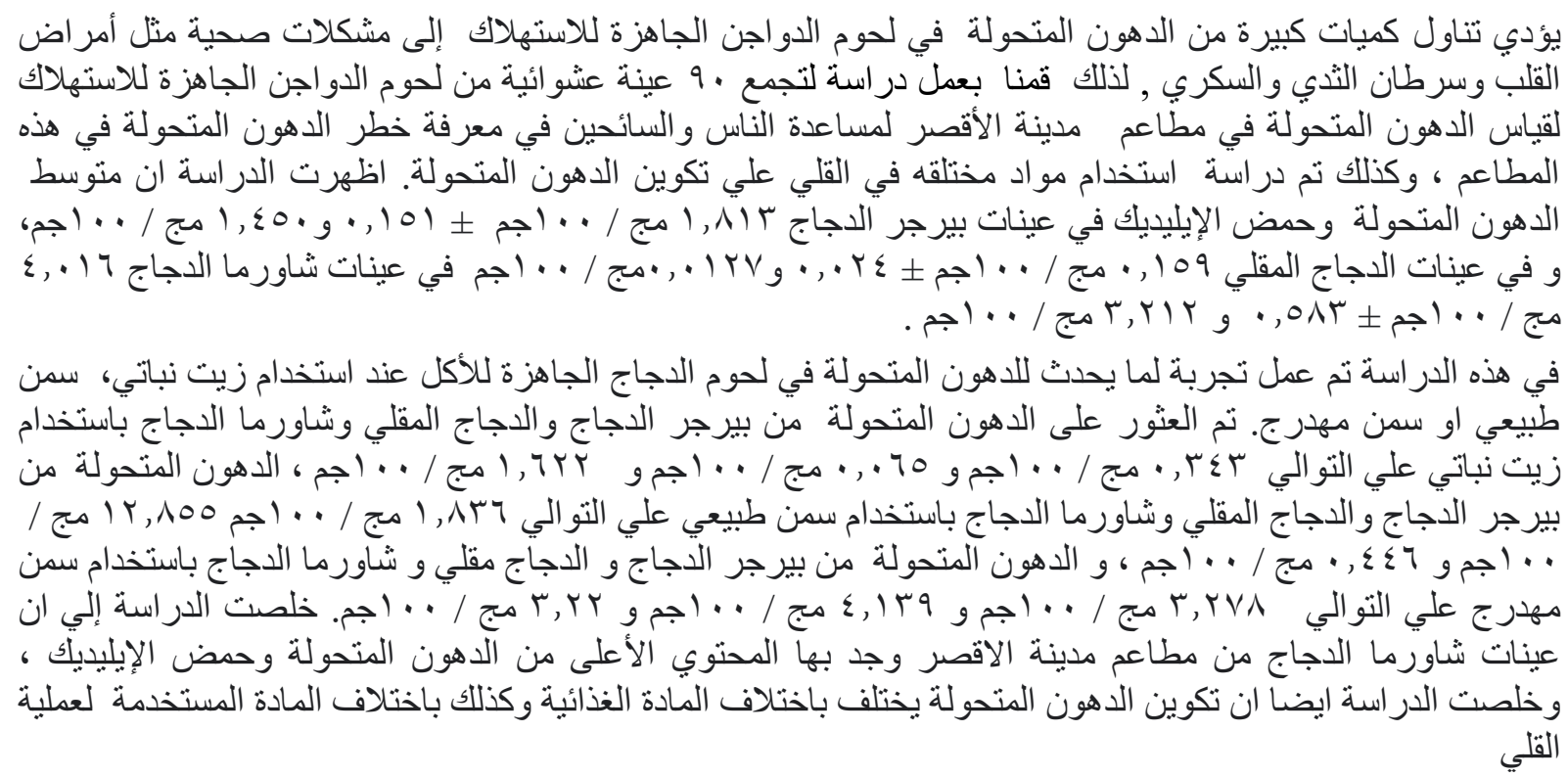

